\title{
Pengaruh Penerapan LKPD Berdasarkan Kerangka Kerja TPACK Terhadap Hasil Belajar Matematika Siswa SMP Ditinjau Dari Pemecahan Masalah
}

\author{
Siti Karlina Sari ${ }^{1}$, Syaiful$^{2}$, Evita Anggereini ${ }^{3}$ \\ 1, 2,3 Program Studi Magister Pendidikan Matematika, Universitas Jambi \\ Jl. Raden Mattaher No.16-Jambi, Kota Jambi, Indonesia \\ sitikarlina.sari@yahoo.com
}

\begin{abstract}
The purpose of this study was to determine: (1) effect of the implementation of LKPD based on the TPACK framework on students' mathematical problem solving (2) effect of mathematical problem's solving abilities on student learning outcomes (3) interaction between the application of LKPD and mathematical problem's solving abilities on students learning outcomes. This research was quasi experimental research with posttest research design only control group design. The population were students of class VIII SMPN 20 Jambi City 2020/2021. Sample was taken using simple random sampling. The instrument used was learning outcome test and documentation. The results showed that (1) there was no effect of the application of LKPD based on the TPACK framework on students' mathematical problem solving because the significance value of two-way ANOVA was 0.058 , greater than 0.05 . (2) there is an effect of mathematical problem's solving ability on student learning outcomes because the significance value of two-way ANOVA was 0.000, lower than 0.05. (3) there is no interaction between the application of LKPD and students' mathematical problem's solving abilities on learning outcomes because the significance value of two-way ANOVA was 0.364, greater than 0.05 .
\end{abstract}

Keywords: LKPD, TPACK Framework, Mathematics Learning Outcomes, Problem Solving

\begin{abstract}
Abstrak
Tujuan penelitian ini adalah untuk mengetahui: (1) apakah terdapat pengaruh penerapan LKPD berdasarkan kerangka kerja TPACK terhadap pemecahan masalah matematika siswa (2) apakah terdapat pengaruh kemampuan pemecahan masalah matematika terhadap hasil belajar siswa (3) apakah terdapat interaksi antara penerapan LKPD dan hasil belajar terhadap kemampuan pemecahan masalah matematika siswa. Jenis penelitian ini adalah quasi experimental research dan desain penelitian posttest only control group design. Populasi penelitian adalah siswa kelas VIII SMPN 20 Kota Jambi tahun ajaran 2020/2021. Pengambilan kelas sampel dilakukan dengan teknik simple random sampling. Instrumen yang digunakan tes hasil belajar dan dokumentasi. Hasil penelitian menunjukkan bahwa (1) tidak terdapat pengaruh penerapan LKPD berdasarkan kerangka kerja TPACK terhadap pemecahan masalah matematika siswa yang dapat dilihat dari nilai signifikasi dengan analisis data menggunakan ANOVA dua jalur yaitu 0.058 , lebih besar dari 0.05. (2) terdapat pengaruh kemampuan pemecahan masalah matematika terhadap hasil belajar siswa yang dapat dilihat dari nilai signifikasi dengan analisis data menggunakan ANOVA dua jalur yaitu 0.000 , lebih kecil dari 0.05. (3) tidak terdapat interaksi antara penerapan LKPD dan kemampuan pemecahan masalah matematika siswa terhadap hasil belajar siswa, yang dapat dilihat dari nilai signifikasi dengan analisis data menggunakan ANOVA dua jalur yaitu 0.364, lebih besar dari 0.05 .
\end{abstract}

Kata kunci: LKPD, Kerangka Kerja TPACK, Hasil Belajar Matematika, Pemecahan Masalah

Copyright (c) 2021 Siti Karlina Sari, Syaiful, Evita Anggereini

$\triangle$ Corresponding author: Siti Karlina Sari

Email Address: sitikarlina.sari@yahoo.com (Jl. Raden Mattaher No.16-Jambi, Kota Jambi, Indonesia)

Received 06 April 2021, Accepted 09 April 2021, Published 10 April 2021

\section{PENDAHULUAN}

Pemahaman konsep yang siswa peroleh merupakan sesuatu yang abstrak. Pembelajaran kontekstual sebagai suatu pendekatan pembelajaran yang memberikan fasilitas kegiatan belajar untuk mencari, mengolah, dan menemukan pengalaman belajar yang terkait dengan kehidupan nyata melalui keterlibatan aktivitas siswa dalam mencoba, melakukan, dan mengalami sendiri. Dengan demikian pembelajaran tidak hanya dilihat dari hasil belajar tetapi juga proses belajar. Selain itu, media 
pembelajaran juga sangat diperlukan dalam proses pembelajaran karena pada dasarnya saat ini manusia hidup pada abad ke -21 dan berada di era revolusi 4.0 di mana perkembangan teknologi yang semakin pesat, menurut Sutrisno (2011) sangat memungkinkan peran TIK dalam kegiatan belajar mengajar untuk mencapai tujuan pembelajaran dengan hasil yang lebih baik.

TIK dalam pembelajaran merupakan fasilitas pendidikan sebagai alat bantu bahkan sebagai alat penunjang administrasi pendidikan di mana tujuan dari penggunaan TIK yaitu siswa difasilitasi secara memadai untuk membentuk proses belajar mandiri sehingga mendapat pembelajaran yang aktif dan kreatif. Guru sebagai fasilitator berusaha memfasilitasi siswa untuk membantu siswa dalam belajar, salah satu usahanya adalah dengan menyediakan bahan ajar yang menarik dengan tujuan dapat memotivasi siswa dan dapat membuat siswa belajar secara mandiri tanpa harus selalu didampingi guru. Kurangnya pengetahuan dan informasi sebelum belajar di kelas, guru haruslah membekali pengetahuan dan informasi supaya pembelajaran dapat aktif sebagaimana yang diharapkan. Untuk mengatasinya, dapat dilakukan dengan menyiapkan bahan ajar untuk siswa seperti modul, media, alat peraga dan bahan ajar lainya yang bersifat elektronik maupun non elektronik.

Pada proses pembelajaran guru sudah menerapkan TIK dengan menggunakan model pembelajaran yang sesuai dengan materi pelajaran, dalam proses pembelajaran itu sendiri terdapat perpaduan antara teknologi sebagai media pembelajaran dan pedagodi yang diterapkan dalam proses pembelajaran untuk menjelaskan sebuah materi pelajaran yang mana perpaduan tersebut memiliki peranan penting dan saling berkontribusi terhadap keoptimalan pemecahan masalah siswa. Untuk mengkolaborasi peran dari teknologi, pedagogi dan materi pelajaran yang menuju pada hasil belajar siswa dan keterampilan pemecahan masalah siswa dengan menggunakan model kontekstual dapat menggunakan kerang kerja TPACK (Technological, Pedagogical, Content Knowledge).

TPACK merupakan pembelajaran yang memanfaatkan teknologi yang hasilnya sangat baik untuk memahami konsep materi (Lu, 2014). Menurut Koehler, M., \& Mishra (2008), ada tiga komponen yang harus dikuasai oleh pendidik, yakni penguasaan materi bidang studi yang harus sesuai dengan kualifikasi dan kompetensi yang dimilikinya, pedagogi dan teknologi.

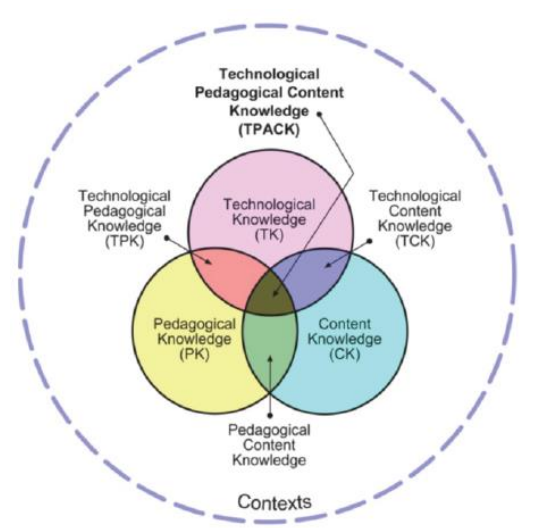

Gambar 1. TPACK (Koehler, M., \& Mishra, 2009) 
Pengaruh Penerapan LKPD Berdasarkan Kerangka Kerja TPACK Terhadap Hasil Belajar Matematika Siswa SMP Ditinjau Dari Pemecahan Masalah, Siti Karlina Sari, Syaiful, Evita Anggereini

TPACK merupakan kerangka kerja yang kompleks dan saling berhubungan antara komponen penyusunya, antara lain TK (Technological, Knowledge), PK (Pedagogical, Knowledge) dan CK (Content Knowledge). Hal tersebut menekankan hubungan dan kompleksitas antara tiga komponen sehingga terdapat keterkaitan antara (PCK), (TCK) dan (TPK) (Sutrisno, 2012), TPACK memberikan konsep yang mampu mengintegrasikan ketiga komponen yang penting dalam proses pembelajaran, ketiganya saling berinteraksi satu sama lain untuk menghasilkan pembelajaran berbasis teknologi. Dengan mengintegrasikan teknologi berupa LKPD yang disajikan dalam sofware $3 D$ pageflip profesional yang sesuai dengan materi Sistem Persamaan Linear Dua Variabel (SPLDV) dengan menggunakan model kontekstual diaharapkan konsep materi menjadi lebih konkrit sehingga siswa lebih mudah memahami materi serta indikator dapat tercapai.

Masalah adalah suatu keadaan dimana pengetahuan yang tersimpan di dalam memori untuk melakukan suatu tugas pemecahan masalah belum siap dipakai (Krulik \& Rudnick, 2010). Menurut Polya, pemecahan masalah sebagai jalan keluar dari suatu kesulitan untuk mencapai suatu tujuan yang tidak begitu segera dapat dicapai (Sutarto, 2014). Menurut Posamentier, A. \& Krulik (2009), saat ini pemecahan masalah merupakan hal yang penting dalam pembelajaran matematika dan merupakan bagian dari kurikulum yang harus diajarkan oleh guru kepada siswa. Pentingnya pemilikan kemampuan pemecahan masalah oleh siswa dalam matematika dikemukakan oleh Branca (Syaiful, 2012), (1) kemampuan pemecahan masalah merupakan tujuan umum pengajaran matematika, bahkan sebagai jantungnya matematika; (2) pemecahan masalah meliputi metode, prosedur dan strategi merupakan proses inti dan utama dalam kurikulum matematika; (3) pemecahan masalah merupakan kemampuan dasar dalam belajar matematika.

Konsep dasar TPACK sangat berhubungan dengan pengembangan aktivitas pembelajaran karena proses yang lebih kompleks, situasional dan dinamis. Dengan mengintegrasikan materi, pedagogi dan teknologi akan menggambarkan adanya daya tarik untuk menumbuhkan pembelajaran yang aktif dan terfokus pada siswa (Koehler, M., \& Mishra, 2008). TIK dan kerangka kerja TPACK yang diterapkan pada materi Sistem Persamaan Linear Dua Variabel (SPLDV) dengan menggunakan sofware $3 D$ pageflip profesional diyakini dapat memberikan peluang dalam menyelesaikan persoalan yang ditemukan dalam pembelajaran matematika, dan siswa belajar lebih aktif, kreatif dan proses pembelajaran lebih bermakna.

a. Pedagogy Content Knowledge (PCK) merupakan irisan antara pedagogi dengan materi pelajaran. Hal ini mencakup proses pembelajaran yang terkait dengan materi pelajaran yang dipelajari siswa.

b. Technology Content Knowledge (TCK) termasuk dalam pemahaman teknologi dan materi pelajaran yang dapat membantu serta mempengaruhi komponen-komponen yang lain.

c. Technology Pedagogy Knowledge (TPK) merupakan serangkaian pemahaman bagaimana perubahan pembelajaran terjadi dengan memanfaatkan teknologi yang digunakan untuk mendukung pembelajaran dan membantu mempermudah konsep pelajaran yang dipelajari siswa. 
d. Technology Pedagogy Content Knowledge (TPACK) merupakan rangkaian dalam proses pembelajaran di mana teknologi terintegrasi dengan komponen penyusunanya $(\mathrm{C}),(\mathrm{P})$, dan $(\mathrm{K})$. TPACK mengisyaratkan terjadinya multi interaksi dan kombinasi antar komponen yakni materi pelajaran, pedagogi dan teknologi yang unik dan bersinegis berbasis TIK.

Untuk itu penulis mengambil judul dalam penelitian ini yaitu "Pengaruh Penerapan LKPD Berdasarkan Kerangka Kerja TPACK Terhadap Hasil Belajar Matematika Siswa SMP Ditinjau Dari Pemecahan Masalah".

\section{METODE}

Jenis penelitian yang digunakan adalah quasi experimental research atau penelitian eksperimen semu. Quasi experiment research digunakan dalam penelitian ini karena penelitian dilaksanakan pada kelompok belajar (kelas) yang sudah ada dan tidak memungkinkan peneliti untuk mengubah struktur kelas yang sudah ada. Jenis desain penelitian ini adalah posttest only control group design.

Tabel 1. Desain Quasi Eksperiment (Posttest Only Control Group Design)

\begin{tabular}{|c|c|c|c|}
\hline Kelompok & Pre-test & Perlakuan & Post-test \\
\hline Eksperimen 1 & $O_{1}$ & $X_{1}$ & $O_{2}$ \\
\hline Eksperimen 2 & $O_{3}$ & $X_{2}$ & $O_{4}$ \\
\hline Kontrol & $O_{5}$ & $Y$ & $O_{6}$ \\
\hline
\end{tabular}

Penelitian ini dilakukan pada bulan Januari 2021 dengan materi Sistem Persamaan Linear Dua Variabel (SPLDV). Populasi pada penelitian ini adalah siswa kelas VIII SMPN 20 Kota Jambi dan sampelnya yakni kelas VIII C, VIII F dan VIII G yang dipilih dengan teknik simple random sampling atau yang dikenal dengan sampel acak setelah populasi dinyatakan normal dan homogen. Adapun kelas VIII C merupakan kelas eksperimen 1 yang diajarkan dengan pemberian LKPD 1 berkerangka kerja TPACK, kelas VIII G merupakan kelas eksperimen 2 yang diajarkan dengan pemberian LKPD 2 berkerangka kerja TPACK dan kelas VIII F sebagai kelas kontrol yang diajarkan dengan pembelajaran langsung. pembelajaran dilaksanakan secara online dengan menggunakan aplikasi Zoom Cloud Meeting.

Data dalam penelitian ini adalah data tes kemampuan awal siswa yang dikumpulkan dengan instrumen pretest, data keterlaksanaan proses pembelajaran yang dikumpulkan dengan instrumen lembar observasi dan data tes kemampuan pemecahan masalah siswa yang dikumpulkan dengan instrumen posttest materi Sistem Persamaan Linear Dua Variabel (SPLDV). Sebelum penelitian, instrumen divalidasi terlebih dahulu oleh satu orang ahli instrumen, setelah didapatkan penilaian yang valid dan tidak perlu direvisi lagi maka instrumen dapat digunakan untuk penelitian. Setelah menyiapkan keperluan penelitian, peneliti memberikan pretest kepada siswa kelas eksperimen dan kelas kontrol, kemudian kedua kelas eksperimen diberikan perlakuan dengan pemberian LKPD dengan kerangka kerja TPACK, setelah itu ketiga kelas diberikan soal posttest pemecahan masalah. Setelah data terkumpul maka data dianalisis dengan menggunakan anova dua jalur dan Uji Tukey. 
Pengaruh Penerapan LKPD Berdasarkan Kerangka Kerja TPACK Terhadap Hasil Belajar Matematika Siswa SMP Ditinjau Dari Pemecahan Masalah, Siti Karlina Sari, Syaiful, Evita Anggereini

\section{HASIL DAN DISKUSI}

Hasil

Uji normalitas bertujuan untuk mengetahui apakah data hasil kemampuan awal siswa kelas eksperimen 1 yang diperoleh dalam penelitian berdistribusi normal atau tidak. Adapun hasil perhitungan uji normalitas disajikan dalam Tabel 2 berikut ini

Tabel 2. Hasil Uji Normalitas Kemampuan Awal Siswa

\begin{tabular}{|l|c|c|c|c|}
\hline \multirow{2}{*}{} & \multirow{2}{*}{ Kelas } & \multicolumn{3}{|c|}{ Shapiro-Wilk } \\
\cline { 3 - 5 } & & Statistic & df & Sig. \\
\hline $\begin{array}{l}\text { Tes Awal } \\
\text { Siswa }\end{array}$ & Eksperimen 1 & 0,957 & 27 & 0,310 \\
\hline
\end{tabular}

Dari Tabel 1 uji normalitas data tes awal siswa dengan uji Shapiro-Wilk untuk kelas eksperimen 1 memperoleh nilai sign. 0,310 >0,05 yang berarti $\mathrm{H}_{0}$ diterima, atau dapat disimpulkan bahwa kelas eksperimen tersebut berdistribusi normal.

Adapun hasil perhitungan uji normalitas kelas eksperimen 2 disajikan dalam Tabel 3 berikut ini:

Tabel 3. Hasil Uji Normalitas Kemampuan Awal Siswa

\begin{tabular}{|c|c|c|c|c|}
\hline & \multirow[b]{2}{*}{ Kelas } & \multicolumn{3}{|c|}{ Shapiro-Wilk } \\
\hline & & Statistic & df & Sig. \\
\hline $\begin{array}{l}\text { Tes Awal } \\
\text { Siswa }\end{array}$ & Eksperimen 2 & 0,935 & 30 & 0,068 \\
\hline
\end{tabular}

Dari Tabel 2 uji normalitas data tes awal siswa dengan uji Shapiro-Wilk untuk kelas eksperimen 2 memperoleh nilai sign. 0,068 > 0,05 yang berarti $\mathrm{H}_{0}$ diterima, atau dapat disimpulkan bahwa kedua kelas eksperimen tersebut berdistribusi normal.

Adapun hasil perhitungan uji normalitas kelas kontrol disajikan dalam Tabel 4 berikut ini:

Tabel 4. Hasil Uji Normalitas Kemampuan Awal Siswa

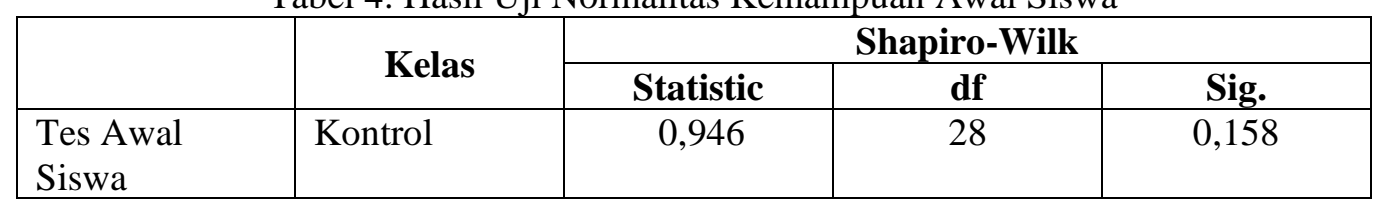

Dari Tabel 3 uji normalitas data tes awal siswa dengan uji Shapiro-Wilk untuk kelas kontrol memperoleh nilai sign. 0,158>0,05 yang berarti $\mathrm{H}_{0}$ diterima, atau dapat disimpulkan bahwa kelas kontrol tersebut berdistribusi normal. Adapun hasil uji homogenitas data pretest siswa yaitu sebagai berikut:

Tabel 5. Uji Homogenitas Tes Kemampuan Awal Siswa

\begin{tabular}{|c|c|c|c|}
\hline Levene Statistic & df1 & df2 & Sig. \\
\hline 0,137 & 2 & 82 & 0,873 \\
\hline
\end{tabular}


Berdasarkan hasil uji homogenitas yang telah disajikan pada Tabel 5 terlihat bahwa data tes awal siswa memiliki nilai signifikansi $0,873>0,05$ maka $\mathrm{H}_{0}$ diterima yang berarti bahwa data memiliki variansi yang sama atau homogen.

Setelah data diuji normalitas dan homogenitas, langkah selanjutnya adalah siswa diberikan perlakuan. Siswa pada kelas eksperimen 1 dan eksperimen 2 diberikan perlakuan pembelajaran dengan pemberian LKPD dengan kerangka kerja TPACK dan siswa pada kelas kontrol diberikan perlakuan pembelajaran langsung, proses pembelajaran dilaksanakan secara online. Setelah ketiga kelas diberikan perlakuan kemudian siswa diberi tes kemampuan pemecahan masalah siswa yang dikumpulkan dengan instrumen posttest.

Data nilai posttest terlebih dahulu diuji normalitas dan homogenitas sebagai prasyarat untuk uji hipotesis. Adapun hasil uji normalitas dan homogenitas nilai posttest sebagai berikut.

Tabel 6. Uji Normalitas Data Posttest Kemampuan Pemecahan Masalah Matematika Siswa

\begin{tabular}{|l|c|c|c|c|}
\hline \multirow{2}{*}{\begin{tabular}{l}
\multirow{2}{*}{$\begin{array}{l}\text { Kemampuan } \\
\text { Pemecahan } \\
\text { Masalah }\end{array}$} \\
\cline { 3 - 5 }
\end{tabular}} & Eksperimen 1 & Statistic & df & Sig. \\
\hline
\end{tabular}

Dari Tabel 6 uji normalitas data kemampuan pemecahan masalah matematika siswa dengan uji ShapiroWilk untuk kelas eksperimen 1 memperoleh nilai sign. 0,782 > 0,05 yang berarti $\mathrm{H}_{0}$ diterima, atau dapat disimpulkan bahwa kelas eksperimen 1 tersebut berdistribusi normal.

Tabel 7. Uji Normalitas Data Posttest Kemampuan Pemecahan Masalah Matematika Siswa

\begin{tabular}{|l|c|c|c|c|}
\hline \multirow{2}{*}{} & \multirow{2}{*}{ Kelas } & \multicolumn{3}{|c|}{ Shapiro-Wilk } \\
\cline { 3 - 5 } & & Statistic & df & Sig. \\
\hline $\begin{array}{l}\text { Kemampuan } \\
\text { Pemecahan } \\
\text { Masalah }\end{array}$ & Eksperimen 2 & 0,943 & 30 & 0,110 \\
\hline
\end{tabular}

Dari Tabel 7 uji normalitas data kemampuan pemecahan masalah matematika siswa dengan uji ShapiroWilk untuk kelas eksperimen 2 memperoleh nilai sign. 0,110>0,05 yang berarti $\mathrm{H}_{0}$ diterima, atau dapat disimpulkan bahwa kedua kelas eksperimen tersebut berdistribusi normal.

Tabel. 8. Uji Normalitas Data Posttest Kemampuan Pemecahan Masalah Matematika Siswa

\begin{tabular}{|l|l|c|c|c|}
\hline \multirow{2}{*}{\begin{tabular}{l}
\multirow{2}{*}{$\begin{array}{l}\text { Kemampuan } \\
\text { Pemecahan } \\
\text { Masalah }\end{array}$} \\
\cline { 3 - 5 }
\end{tabular}} & Kontrol & Statistic & df & Sig. \\
\hline
\end{tabular}


Dari tabel 8 uji normalitas data kemampuan pemecahan masalah matematika siswa dengan uji ShapiroWilk untuk kelas kontrol memperoleh nilai sign. 0,127 > 0,05 yang berarti $\mathrm{H}_{0}$ diterima, atau dapat disimpulkan bahwa kelas Kontrol tersebut berdistribusi normal.

Tabel 9. Uji Homogenitas Data Posttest Kemampuan Pemecahan Masalah Matematika Siswa

\begin{tabular}{|c|c|c|c|}
\hline Levene Statistic & df1 & df2 & Sig. \\
\hline 0,250 & 2 & 82 & 0,780 \\
\hline
\end{tabular}

Dari Tabel 9 terlihat bahwa nilai signifikansi $0,780>0,05$ yang artinya bahwa $\mathrm{H}_{0}$ diterima atau dapat disimpulkan bahwa data pada masing-masing sampel berasal dari populasi yang sama (homogen). Pengujian hipotesis dilakukan dengan menggunakan uji Univariate Analysis of Variance (ANOVA) dua jalur. Pengujian ini menggunakan aplikasi SPSS.23 dengan taraf signifikansi $5 \%$. Jika taraf signifikansi $>0,05$ maka $\mathrm{H}_{0}$ diterima. Dan jika nilai signifikansi < 0,05 maka $\mathrm{H}_{0}$ ditolak. Berikut hasil uji ANOVA dua jalur yang akan disajikan pada Tabel 10.

Tabel 10. Rangkuman Analisis Varian Dua Jalur

\begin{tabular}{|l|r|r|r|r|l|}
\hline \multicolumn{1}{|c|}{ Source } & \multicolumn{1}{c|}{$\begin{array}{c}\text { Type III Sum of } \\
\text { Squares }\end{array}$} & \multicolumn{1}{c|}{ df } & Mean Square & \multicolumn{1}{c|}{ F } & \multicolumn{1}{c|}{ Sig. } \\
\hline $\begin{array}{l}\text { Corrected } \\
\text { Model }\end{array}$ & $25291,882^{\mathrm{a}}$ & 8 & 3161,485 & 59,929 & 0,000 \\
\hline Intercept & 369943,935 & 1 & 369943,935 & 7012,640 & 0,000 \\
\hline KPM & 23935,135 & 2 & 11967,568 & 226,857 & 0,000 \\
\hline KodeKelas & 311,810 & 2 & 155,905 & 2,955 & 0,058 \\
\hline $\begin{array}{l}\text { KPM } * \\
\text { KodeKelas }\end{array}$ & 231,493 & 4 & 57,873 & 1,097 & 0,364 \\
\hline Error & 4009,295 & 76 & 52,754 & & \\
\hline Total & 394300,000 & 85 & & & \\
\hline Corrected Total & 29301,176 & 84 & & & \\
\hline
\end{tabular}

Berdasarkan data pada Tabel 9 di atas diperoleh hasil:

1. Hipotesis 1

Terdapat pengaruh penerapan LKPD berdasarkan kerangka kerja TPACK terhadap pemecahan masalah matematika siswa.

$H_{0}: \mu_{1}=\mu_{2}=\mu_{3}$

$H_{1}: \mu_{1} \neq \mu_{2}=\mu_{3} \quad$ atau $\quad H_{1}: \mu_{1}=\mu_{2} \neq \mu_{3}$

Pengaruh penerapan LKPD berdasarkan kerangka kerja TPACK terhadap pemecahan masalah matematika siswa dapat dilihat dari $F_{\text {hitung }}$ yang diperoleh 2,955 dengan nilai signifikansi 0,058.

Karena nilai signifikansi 0,058 $>0,05$ sehingga $\mathrm{H}_{0}$ diterima dan dapat disimpulkan bahwa tidak terdapat pengaruh penerapan LKPD berdasarkan kerangka kerja TPACK terhadap pemecahan masalah matematika siswa.

2. Hipotesis 2

Terdapat pengaruh kemampuan pemecahan masalah matematika terhadap hasil belajar siswa. 


$$
\begin{aligned}
& H_{0}: a_{1}=a_{2}=a_{3} \\
& H_{1}: a_{1}=a_{2} \neq a_{3} \quad \text { atau } \quad H_{1}: a_{1} \neq a_{2}=a_{3}
\end{aligned}
$$

Pengaruh kemampuan pemecahan masalah matematika terhadap hasil belajar siswa dapat dilihat dari $F_{\text {hitung }}$ yang diperoleh sebesar 226,857 dengan nilai signifikansi 0,000. Karena nilai signifikansi $0,000<0,05$ sehingga $\mathrm{H}_{0}$ ditolak. Artinya terdapat pengaruh kemampuan pemecahan masalah matematika terhadap hasil belajar siswa.

3. Hipotesis 3

Terdapat interaksi antara penerapan LKPD dan kemampuan pemecahan masalah siswa terhadap hasil belajar matematika siswa

$$
\begin{gathered}
H_{0}: \gamma_{1} \times \gamma_{2}=0 \\
H_{1}: \gamma_{1} \times \gamma_{2} \neq 0
\end{gathered}
$$

Interaksi antara penerapan LKPD dan kemampuan pemecahan masalah matematika siswa terhadap hasil belajar dapat dilihat dari $F_{\text {hitung }}$ yang diperoleh sebesar 1,097 dengan nilai signifikansi 0,364. Karena nilai signifikansi 0,364 > 0,05 maka $\mathrm{H}_{0}$ diterima. Sehingga dapat disimpulkan bahwa tidak terdapat interaksi antara penerapan LKPD dan hasil belajar terhadap kemampuan pemecahan masalah matematika siswa.

Uji tukey data posttest kemampuan pemecahan masalah siswa digunakan untuk melihat

\begin{tabular}{|c|c|c|c|c|c|c|}
\hline \multirow[t]{2}{*}{$\begin{array}{l}\text { (I) } \\
\text { KodeKelas }\end{array}$} & \multirow[t]{2}{*}{$\begin{array}{l}\text { (J) } \\
\text { KodeKelas }\end{array}$} & \multirow{2}{*}{$\begin{array}{c}\text { Mean } \\
\text { Difference } \\
(\mathbf{I}-J)\end{array}$} & \multirow{2}{*}{$\begin{array}{l}\text { Std. } \\
\text { Erro } \\
\mathbf{r}\end{array}$} & \multirow[t]{2}{*}{ Sig. } & \multicolumn{2}{|c|}{$\begin{array}{l}\text { 95\% Confidence } \\
\text { Interval }\end{array}$} \\
\hline & & & & & $\begin{array}{l}\text { Lower } \\
\text { Bound }\end{array}$ & $\begin{array}{l}\text { Upper } \\
\text { Bound }\end{array}$ \\
\hline \multirow[t]{2}{*}{ kelas F } & kelas C & $-5,046$ & 5,024 & 0,576 & $-17,04$ & 6,95 \\
\hline & kelas $\mathrm{G}$ & $-7,583$ & 4,894 & 0,273 & $-19,27$ & 4,10 \\
\hline \multirow[t]{2}{*}{ kelas $\mathrm{C}$} & kelas F & 5,046 & 5,024 & 0,576 & $-6,95$ & 17,04 \\
\hline & kelas $\mathrm{G}$ & $-2,537$ & 4,941 & 0,865 & $-14,33$ & 9,26 \\
\hline \multirow[t]{2}{*}{ kelas $\mathrm{G}$} & kelas F & 7,583 & 4,894 & 0,273 & $-4,10$ & 19,27 \\
\hline & kelas C & 2,537 & 4,941 & 0,865 & $-9,26$ & 14,33 \\
\hline
\end{tabular}
seberapa besar nilai perbedaan rata-rata yang diperoleh oleh setiap kelas berdasarkan perlakuan yang diberikan pada masing-masing kelas. Data hasil uji tersebut akan di sajikan pada Tabel 11 di bawah ini.

Tabel 11. Uji Tukey Data Posttest Kemampuan Pemecahan Masalah

Berdasarkan tabel di atas terlihat bahwa model pembelajaran direct instruction dengan pemberian LKPD eksperimen 1 memiliki nilai sign. 0,576>0,05 dan model direct instruction dengan pembelajaran pemberian LKPD eksperimen 2 memiliki nilai sign. 0,273>0,05 dengan demikian dapat disimpulkan bahwa antara siswa yang diberi perlakuan pembelajaran model direct instruction dengan pembelajaran pemberian LKPD tidak memiliki perbedaan. Dan antara pemberian LKPD eksperimen 1 dengan pemberian LKPD eksperimen 2 memiliki nilai sign. 0,865 > 0,05 yang berarti bahwa tidak terdapat perbedaan hasil kemampuan pemecahan masalah matematika. 
Pengaruh Penerapan LKPD Berdasarkan Kerangka Kerja TPACK Terhadap Hasil Belajar Matematika Siswa SMP Ditinjau Dari Pemecahan Masalah, Siti Karlina Sari, Syaiful, Evita Anggereini

\section{Diskusi}

\section{Pengaruh Penerapan LKPD Berdasarkan Kerangka Kerja TPACK Terhadap Pemecahan Masalah Matematika Siswa}

Berdasarkan analisis dua jalur yang telah diperoleh $\mathrm{H}_{0}$ diterima dan dapat disimpulkan bahwa tidak terdapat pengaruh penerapan LKPD berdasarkan kerangka kerja TPACK terhadap pemecahan masalah matematika siswa. Dari hasil pengolahan data yang diperoleh kemampuan pemecahan matematika siswa yang mengikuti pembelajaran dengan pemberian LKPD berkerangka kerja TPACK pada materi Sistem Persamaan Linear Dua Variabel (SPLDV) tidak lebih baik dibandingkan dengan model pembelajaran Direct Instruction (DL). Hasil ini sesuai dengan hipotesis pertama.

Saat penelitian terdapat faktor yang tidak bisa dikendalikan oleh peneliti salah satunya yakni apresiasi matematika dari siswa, dalam proses pembelajaran siswa tidak memberikan apresiasi terhadap matematika itu sendiri hal tersebut terlihat saat siswa diberikan contoh soal dan soal latihan. Siswa enggan mengerjakan soal dengan menuliskan langkah-langkah penyelesaianya, kebanyakan siswa menerka-nerka jawaban dari soal tersebut. Sehingga proses penyelesaian masalah menurut Polya (Nisaa, 2020) yaitu memahami dan mengeksplorasi masalah (understand), merancang cara menyelesaikan masalah atau strategi, menggunakan strategi untuk memecahkan masalah (solve), melihat kembali dan melakukan refleksi terhadap solusi yang diperoleh (looking back) belum terlihat pada siswa.

Banyak faktor yang mempengaruhi pemecahan masalah matematika siswa seperti yang diungkapkan Irawan, Suharta, \& Saputra (2016) dalam penelitianya terdapat 3 faktor yang mempengaruhi pemecahan masalah matematika siswa yaitu pengetahuan awal, kecerdasan logis matematis, dan apresiasi matematika sangat berperan dalam kemampuan pemecahan masalah matematika. Masing-masing indikator ketiga faktor tersebut memiliki peranan dalam tahapan-tahapan pemecahan masalah matematika.

\section{Pengaruh Kemampuan Pemecahan Masalah Matematika Terhadap Hasil Belajar Siswa}

Berdasarkan analisis dua jalur yang telah dilakukan terlihat bahwa $\mathrm{H}_{0}$ ditolak. Artinya terdapat pengaruh kemampuan pemecahan masalah matematika terhadap hasil belajar siswa. Dari hasil pengolahan data yang diperoleh dapat ditarik kesimpulan bahwa siswa yang memiliki kemampuan pemecahan masalah matematika akan mendapatkan hasil belajar lebih tinggi dari pada siswa yang tidak memiliki kemampuan pemecahan masalah matematika.

Siswa yang memiliki kemampuan pemecahan masalah matematika cenderung lebih aktif dalam proses pembelajaran sehingga memberikan nilai positif bagi siswa. Dan terlihat pada hasil postest di mana siswa tersebut sangat tersusun dalam mengerjakan soal yang diberikan sesuai dengan teori proses pemecahan masalah dengan empat tahap Polya (Nissa, 2020) yakni Memahami dan mengeksplorasi masalah (Understand), merancang cara menyelesaikan masalah atau strategi, menggunakan strategi untuk memecahkan masalah (Solve), melihat kembali dan melakukan refleksi terhadap solusi yang diperoleh (Looking back). 
Sementara siswa yang tidak memiliki kemampuan pemecahan masalah matematika terlihat kurang aktif saat proses pembelajaran, mereka cenderung diam saat tidak memahami materi yang dijelaskan oleh guru sehingga menyebabkan siswa tersebut kurang memahami konsep dari materi yang dipelajari, sehingga siswa tersebut sulit untuk menyelesaikan permasalahan yang diberikan. Hal tersebut terlihat pada hasil posttest yang diberikan, di mana siswa yang tidak memiliki kemampuan pemecahan masalah tidak melakukan atau tidak memuliskan langkah-langkah pemecahan masalah.

Hal tersebut sesuai dengan penelitian Yuliati (2018), yang menyatakan bahwa pengaruh anatara kemampuan pemecahan masalah terhadap hasil belajar matematika sebesar $66 \%$ sedangkan $34 \%$ dipengaruhi oleh variabel lain.

\section{Interaksi Antara Penerapan LKPD Dan Kemampuan Pemecahan Masalah Matematika Terhadap Hasil Belajar Siswa}

Berdasarkan uji analisis dua jalur yang telah dilakukan dapat terlihat bahwa Hoditerima. Sehingga dapat disimpulkan bahwa tidak terdapat interaksi antara penerapan LKPD dan hasil belajar terhadap kemampuan pemecahan masalah matematika siswa. Terdapat beberapa faktor sebagai kendala saat proses pembelajaran seperti ketidaksiplinan siswa dalam mengumpulkan tugas yang diberikan oeh guru. Guru sudah mengingatkan batas waktu yang telah ditentukan, akan tetapi sebagian siswa mengabaikan kewajibanya. Selain itu, saat proses pembelajaran banyak siswa yang tidak menghidupkan video, setelah guru menegur siswa barulah siswa menghidupkan video hal tersebut sesuai dengan yang diungkapkan oleh Ardila \& Hartanto (2017), banyak faktor yang mempengaruhi hasil belajar matematika siswa seperti yang diungkapkan dalam penelitianya terdapat 4 faktor yang mempengaruhi hasil belajar siswa yaitu kurangnya minat siswa terhadap pelajaran matematika, kurangnya konsentrasi siswa dalam memperhatikan guru yang sedang menjelaskan, kurangnya pemahaman konsep matematika dasar siswa, serta ketidaksiplinan siswa dalam mengumpulkan tugas yang diberikan oleh guru.

\section{KESIMPULAN}

Berdasarkan hasil dan diskusi diatas dapat disimpulkan bahwa: (1) tidak terdapat pengaruh penerapan LKPD berdasarkan kerangka kerja TPACK terhadap pemecahan masalah matematika siswa, (2) terdapat pengaruh kemampuan pemecahan masalah matematika terhadap hasil belajar siswa, dan (3) tidak terdapat interaksi antara penerapan LKPD dan kemampuan pemecahan masalah siswa terhadap hasil belajar matematika siswa.Banyak faktor yang mempengaruhi pemecahan masalah matematika siswa, yaitu pengetahuan awal, kecerdasan logis matematis, dan apresiasi matematika sangat berperan dalam kemampuan pemecahan masalah matematika. Selain itu, banyak faktor yang mempengaruhi hasil 
Pengaruh Penerapan LKPD Berdasarkan Kerangka Kerja TPACK Terhadap Hasil Belajar Matematika Siswa SMP Ditinjau Dari Pemecahan Masalah, Siti Karlina Sari, Syaiful, Evita Anggereini

belajar matematika siswa, yaitu kurangnya minat siswa terhadap pelajaran matematika, kurangnya konsentrasi siswa dalam memperhatikan guru yang sedang menjelaskan, kurangnya pemahaman konsep matematika dasar siswa, serta ketidaksiplinan siswa dalam mengumpulkan tugas yang diberikan oleh guru.

\section{UCAPAN TERIMA KASIH}

Peneliti mengucapkan rasa syukur kepada Allah SWT.karena selalu diberikan kelancaran dalam menyelesaikan artikel ini. Peneliti juga mengucapkan terima kasih kepada orangtua dan keluarga yang telah memberi dukungan penuh kepada peneliti. Rasa terima kasih juga peneliti ucapkan kepada pembimbing saya yakni Dr. Syaiful, M.Pd. dan Dr. Evita Anggereini, M.Si. yang telah memberi bimbingan dan arahan dalam menyelesaikan penelitian dan artikel ini. Terakhir, rasa terima kasih ini peneliti ucapkan kepada sahabat-sahabat saya yang selalu memberi dukungan dan semangat.

\section{REFERENSI}

Ardila, A., \& Hartanto, S. (2017). Faktor yang Mempengaruhi Rendahnya Hasil Belajar Matematika Siswa MTS iskandar Muda Batam. 6(2), 175-186.

Irawan, I. P. E., Suharta, I. G. P., \& Suparta, I. N. (2016). Faktor-Faktor Yang Mempengaruhi Kemampuan Pemecahan Masalah Matematika: Pengetahuan Awal, Apresiasi Matematika, Dan Kecerdasan Logis Matematis. Prosiding Seminar Nasional MIPA 2016, 69-73.

Koehler, M., \& Mishra, P. (2008). Introducing Technological Pedagogical Content Knowledge. Paper Presented at the Annual Meeting of the American Educational Research Association New York City, March 24-28, 2008.

Koehler, M., \& Mishra, P. (2009). What is technological pedagogical content knowledge (TPACK). Contemporary issues in technology and teacher eduacation. 9(1), 60-7.

Krulik, S., \& Rudnick, J. A. (2010). Suggestions for Teaching Problem Solving- A Baker's Dozen. School Science and Mathematics. 81(1). https://onlinelibrary.wiley.com/doi/abs/10.1111/j.19498594.1981.tb17120.x

Lu, L. (2014). Cultivating Reflective Practitioners in Technology Preparation: Constructing TPACK through Reflection. Educ. Sci. 2014, 4, 13-35; MIPA SMA N 1 Kota Jambi. Jurnal Ilmiah Dikdaya, $6(2), 12-19$.

Nissa, I. C. (2020). Pemecahan Masalah Matematika (Teori dan Contoh Praktek) (Issue March). Nusa Tenggara Barat. Duta Pustaka Ilmu.

Posamentier, A. \& Krulik, S. (2009). Problem solving in mathematics grade 3-6. USA: Corwin. Princeton University Press.

Sutarto, H. (2014). Metode Pemecahan Masalah Menurut Polya untuk Mengembangkan Kemampuan Siswa dalam Pemecahan Masalah Matematis di Sekolah Menengan Pertama. Jurnal Pendidikan Matematika, 2(1). 53-61.

Sutrisno. (2011). Pengantar Pembelajaran Inovatif. Graha Persada Press.

Sutrisno. (2012). Kreatif Mengembangkan Aktivitas Pembelajaran Berbasis TIK. Referensi.

Syaiful. (2012). Peningkatan Kemampuan Pemecahan Masalah Matematis Melalui Pendekatan 
PendidikanMatematika Realistik. Edumatica, 02(April), 36-44.

Yuliati, M. (2018). Pengaruh Kemampuan Pemecahan Masalah Terhadap Hasil Belajar Matematika Kelas V Sekolah Dasar Islam Terpadu. 16480019, 1-93. http://digilib.uin-suka.ac.id/31869/ 